\title{
Relation between some forms of glaucoma and phenylthiocarbamide tasting
}

\author{
H. KALMUS \\ Galton Laboratory, University College, London
}

\author{
A N D \\ I. LEWKONIA \\ Moorfields Eye Hospital, High Holborn Branch, London, W.C.I
}

Becker and Morton ( $1964 \mathrm{a}, \mathrm{b})$ reported data suggesting significant associations between taster status and glaucoma. In particular they found, in both Caucasian and Negro samples in St. Louis, U.S.A., that there were significantly more non-tasters among patients with "primary open-angle" glaucoma and significantly fewer among those with "primary angle-closure" glaucoma. In addition, they reported an increased prevalence of non-tasters among "primary open-angle" glaucoma suspects without loss of visual field. Small samples of glaucoma patients have since been investigated in Japan in respect of taster status, and the results either supported these findings (Takahashi, 1969) or were inconclusive (Suzuki, Takeuchi, and Kitazawa, r966).

The purpose of this study was to see whether any association between taster status and glaucoma could be demonstrated in a sample of London glaucoma patients.

\section{Methods}

Phenylthiocarbamide tests by the method of Harris and Kalmus (1949) were performed over several months on patients attending the Glaucoma Glinic of Moorfields Eye Hospital, High Holborn Branch; the controls were other patients attending the same hospital and a previously reported group of normal Londoners (Harris and Kalmus, 1949). The diagnosis was based on full glaucoma assessment, including repeated measurements of intraocular pressure, gonioscopy, appearance of the optic discs, and central visual field findings. Altogether 569 patients were investigated in the Glaucoma Clinic, of whom 436 had some overt form of glaucoma and 72 were found to have ocular hypertension (above $24 \mathrm{~mm}$. Hg on repeated occasions without field-loss).

Patients with pseudoexfoliate and pigmentary glaucoma have been classified separately. The rest were non-glaucomatous and were included with the controls. There were twenty non-Caucasians among the sample, and these were excluded from the analysis leaving a total of 418 glaucomatous and seventy hypertensive patients. These were classified as shown in Table I (overleaf).

In Table $I$ it was attempted to classify the patients in the same way as those of Becker and Morton ( $1964 \mathrm{a}, \mathrm{b}$ ), but a separate class had to be formed for those whose type of glaucoma could not be positively determined. 
Table I Taster status among Caucasian glaucoma patients and controls in London, by sex (percentages in brackets)

\begin{tabular}{|c|c|c|c|c|c|c|}
\hline \multirow{3}{*}{ Type of glaucoma } & \multicolumn{6}{|l|}{ Sex } \\
\hline & \multicolumn{2}{|c|}{ Males } & \multicolumn{2}{|c|}{ Females } & \multicolumn{2}{|c|}{ Total } \\
\hline & No. & Non-tasters & No. & Non-tasters & No. & Non-tasters \\
\hline Primary open-angle & 144 & $60(42)$ & 87 & $26(30)$ & 231 & $86(37)$ \\
\hline Primary angle-closure & 22 & $7(32)$ & 38 & I3(34) & 60 & $20(33)$ \\
\hline Ocular hypertension & 34 & I $7(50)$ & 36 & $7(19)$ & 70 & $24(34)$ \\
\hline $\begin{array}{l}\text { Pseudoexfoliate }(6 / \mathrm{I}) \\
\text { and pigmentary (I I/I) }\end{array}$ & I 5 & $2(13)$ & 2 & $o(0)$ & 17 & $2(12)$ \\
\hline $\begin{array}{l}\text { Uncertain or } \\
\text { mixed (primary) }\end{array}$ & $3 \mathrm{I}$ & I $3(42)$ & $3^{I}$ & $13(42)$ & 62 & $26(42)$ \\
\hline $\begin{array}{l}\text { Secondary }(32 / 11) \\
\text { Low tension }(15 / 7) \\
\text { Congenital }(1 / 0)\end{array}$ & 26 & Io(38) & 22 & $8\left(3^{6}\right)$ & $4^{8}$ & $18\left(3^{8}\right)$ \\
\hline $\begin{array}{l}\text { Controls, not } \\
\text { glaucomatous }\end{array}$ & I 34 & $3^{8}(28)$ & 123 & $45(37)$ & 257 & $83(32)$ \\
\hline $\begin{array}{l}\text { Normal Londoners } \\
\text { (Harris and Kalmus, } \\
\text { I949) }\end{array}$ & $44^{1}$ & $139(32)$ & 100 & $30(30)$ & 541 & $\mathbf{I} 69(3 \mathrm{I})$ \\
\hline
\end{tabular}

Of the two relevant comparisons, namely between "primary open-angle" glaucoma and controls, and between "primary angle-closure" glaucoma and controls, the former do show a somewhat increased frequency of non-tasters, 37 per cent. as against $3 \mathrm{I}$ or 32 per cent., but this difference is not significant $\chi^{2}=1 \cdot 308$. Whether the increase in males alone, to 42 per cent. means anything is doubtful. There is no decrease in nontasters among the "primary angle-closure" glaucomas, but if anything a slight increase. Those suffering from ocular hypertension (especially the males) again show a slight increase in non-tasters, but overall the excess is not significant. The other types of glaucoma were not sufficiently numerous to allow a comparison of their taster status with that in the controls.

Table II summarizes the results of previous communications and the present one as far as "primary open-angle", "primary angle-closure", and ocular hypertension (glaucoma suspects, primary open-angle suspects) are concerned.

In "primary open-angle" glaucoma, a significant excess of non-tasters is reported amongst Caucasians and Negroes in St. Louis and among Japanese in Tokyo. In our sample this excess was much smaller, as shown above. In the small sample from Chiba, which is some 50 miles from Tokyo, the non-taster frequency was actually lower.

Among the patients with "primary angle-closure" glaucoma, we found practically no difference in non-taster frequency (33 per cent.) from the controls. Whereas the St. Louis and Tokyo samples showed more or less clear non-taster under-representation, the small Chiba sample showed a slight non-taster deficiency. Among a sample of ocular hypertensives Armaly' (I97I) found that there was "an absence of correlation between taste-testing and ocular tension".

\section{Discussion}

The data in Table II are obviously rather heterogeneous and the question arises whether 
Table II Non-taster frequency in five glaucoma studies, by sex

\begin{tabular}{|c|c|c|c|c|c|c|c|c|c|c|}
\hline \multirow{3}{*}{ Place } & \multirow{3}{*}{ Race } & \multirow{3}{*}{ Date } & \multirow{3}{*}{ Diagnosis } & \multicolumn{7}{|l|}{ Sex } \\
\hline & & & & \multicolumn{2}{|c|}{ Males } & \multicolumn{2}{|c|}{ Females } & \multicolumn{2}{|c|}{ Total } & \multirow{2}{*}{ Method } \\
\hline & & & & No. & Non-tasters & No. & Non-tasters & No. & Non-tasters & \\
\hline \multirow[t]{2}{*}{ London } & Caucasians & 1972 & $\begin{array}{l}\text { Primary open-angle } \\
\text { Primary angle-closure } \\
\text { Ocular hypertension } \\
\text { (over } 24 \mathrm{~mm} . \mathrm{Hg} \text { ) }\end{array}$ & $\begin{array}{r}144 \\
22 \\
34\end{array}$ & $\begin{array}{r}60(42) \\
7(32) \\
17(50)\end{array}$ & $\begin{array}{l}87 \\
38 \\
38\end{array}$ & $\begin{array}{r}26(30) \\
13(34) \\
7(19)\end{array}$ & $\begin{array}{r}231 \\
60 \\
70\end{array}$ & $\begin{array}{l}86(37) \\
20(33) \\
24(34)\end{array}$ & \multirow{2}{*}{$\begin{array}{l}\text { Harris } \\
\text { and } \\
\text { Kalmus } \\
\text { (1949) } \\
\text { 8-cup } \\
\text { test }\end{array}$} \\
\hline & & & Control & 134 & $38(28)$ & 123 & $45(37)$ & 257 & $83(32)$ & \\
\hline \multirow[t]{2}{*}{ St. Louis } & Caucasians & 1964 & $\begin{array}{l}\text { Primary open-angle } \\
\text { Primary angle-closure } \\
\text { Glaucoma suspects } \\
\text { (over } 28 \mathrm{~mm} . \mathrm{Hg} \text { ) }\end{array}$ & $\begin{array}{r}104 \\
44\end{array}$ & $\begin{array}{r}55(53) \\
7(16)\end{array}$ & $\begin{array}{l}107 \\
111\end{array}$ & $\begin{array}{l}56(52) \\
20(18)\end{array}$ & $\begin{array}{r}211 \\
155 \\
95\end{array}$ & $\begin{array}{l}111(53) \\
27(17) \\
40(42)\end{array}$ & \multirow[t]{2}{*}{$\begin{array}{l}\text { Hartmann } \\
\text { (I939) } \\
\text { Modified }\end{array}$} \\
\hline & & & Control & 195 & $57(29)$ & 251 & $68(27)$ & 446 & $125(28)$ & \\
\hline \multirow[t]{2}{*}{ St. Louis } & U.S. Negroes & I 964 & $\begin{array}{l}\text { Primary open-angle } \\
\text { Primary angle-closure } \\
\text { Glaucoma suspects } \\
\text { (over } 28 \mathrm{~mm} . \mathrm{Hg} \text { ) }\end{array}$ & & & & & $\begin{array}{l}89 \\
30 \\
16\end{array}$ & $\begin{array}{r}33(37) \\
0(0) \\
4(25)\end{array}$ & \multirow[t]{2}{*}{$\begin{array}{l}\text { Hartmanr } \\
\text { (1939) } \\
\text { Modified }\end{array}$} \\
\hline & & & Control & & & & & 145 & $25(17)$ & \\
\hline \multirow[t]{2}{*}{ C'hiba } & Japanese & 1966 & $\begin{array}{l}\text { Primary open-angle } \\
\text { Primary angle-closure }\end{array}$ & $\begin{array}{l}2 \mathrm{I} \\
1 \mathrm{I}\end{array}$ & $\begin{array}{l}4(19) \\
3(27)\end{array}$ & $\begin{array}{r}9 \\
29\end{array}$ & $\begin{array}{l}1\left(\begin{array}{ll}1 & 1\end{array}\right) \\
5\left(\begin{array}{ll}1 & 7\end{array}\right)\end{array}$ & $\begin{array}{l}30 \\
40 \\
\end{array}$ & $\begin{array}{l}5(17) \\
8(20)\end{array}$ & \multirow[t]{2}{*}{$\begin{array}{l}\text { Hartmann } \\
\text { (1939) } \\
\text { Modified }\end{array}$} \\
\hline & & & Control & I6 & $6(37)$ & 26 & $4^{(15)}$ & $4^{2}$ & $10(24)$ & \\
\hline \multirow[t]{3}{*}{ Tokyo } & Japanese & г969 & $\begin{array}{l}\text { Primary open-angle } \\
\text { Primary angle-closure } \\
\text { Primary open-angle }\end{array}$ & $\begin{array}{l}66 \\
2 \mathrm{I}\end{array}$ & & $\begin{array}{l}41 \\
22\end{array}$ & & $\begin{array}{r}107 \\
43\end{array}$ & $\begin{array}{l}3 I(29) \\
4(9) *\end{array}$ & \multirow{3}{*}{$\begin{array}{l}\text { Hartmann } \\
\text { (1939) } \\
\text { Modified }\end{array}$} \\
\hline & & & $\begin{array}{l}\text { suspects } \\
\text { (over } 24 \mathrm{~mm} . \mathrm{Hg} \text { ) }\end{array}$ & 31 & & 47 & & 78 & I5(I9) & \\
\hline & & & Control & 167 & & 502 & & 669 & I I5 (17) & \\
\hline
\end{tabular}

*omitted from summary

the reported differences are caused by differences in method or sampling errors, or whether they represent genuine population differences.

Becker's PTC solutions were the same as ours but those used in Japan were slightly different. More important, the 8-tumbler test which detects a difference from water was used only by us, whereas something approaching the serial dilution method of Hartmann ( 1939 ) which determines the "recognition threshold" rather than a "detection threshold" was employed in the other investigations. The recognition of a bitter taste is notoriously uncertain and this might explain the high frequencies of non-tasters in the published data. Our test was repeated on sixty subjects from the Glaucoma Clinic in a blind experiment; they were re-tested after periods ranging from a few weeks to several months. The taste threshold of 26 of these subjects remained unchanged, in 22 it differed by one step, and in twelve by two steps. In one of the last group this involved a change from non-taster to taster. The difference in method employed by the various investigators might make some difference, but it is difficult to see why patients and controls should score in opposite ways in the same locality.

There remains, therefore, the possibility that the effects of taster status on the development of the various forms of glaucoma may differ in different ethnic groups. On the other hand, some suspicion must remain concerning the reality of associations between taster status and the two principal classes of glaucoma.

\section{Summary}

In a sample of Londoners, no significant difference was found between the frequency of non-tasters among those with "primary open-angle" and "primary angle-closure" glaucoma, those with ocular hypertension, and controls. This disagrees with previously reported findings. 
We wish to thank Dr. A. Mourant, F.R.S., who drew our attention to the work of Becker and Morton, Mr. J. R. Hudson, Mr. S. J. H. Miller, and Mr. M. Ruben, of Moorfields Eye Hospital, High Holborn Branch, and Mr. J. H. Kelsey, of University College Hospital, for their kind assistance. We should also like to thank Mrs. Debbie Seedburgh for testing the patients and assisting with the preparation of this paper.

\section{References}

ARMAly, M. F. (1971) Personal communication

BECKER, B., and MORTON, w. R. (1964a) Arch. Ophthal. (Chicago), 72, 323

- - $(1964 \mathrm{~b}) \quad$ Science, 144, 1347

HARRIS, H., and Kalmus, H. (1949) Ann. Eugen. (Lond.), 15, 24

HARTMANN, G. (1939) Ibid., 9, I 23

suzuki, Y., TAKeUchi, T., and KitazaWa, y. (1966) Acta Soc. ophthal. jap., 70, 88

TAKAHASHI, T. (1969) Ibid., 73, 37 